\title{
Potential biodiesel production from palm oil, coconut oil and soybean oil for Thailand
}

\author{
Somkiat Khwanpruk and Chalida U-tapao ${ }^{*}$ \\ Department of Civil Engineering, Faculty of Engineering, King Mongkut's Institute of Technology Ladkrabang, Bangkok, Thailand
}

\begin{abstract}
The government began subsidizing the use of B20 in large trucks on a voluntary basis beginning in 2016 and intends to implement the B10 requirement in 2018 for all diesel sales. However, policy makers in both the MOE and the Ministry of Agriculture and Cooperatives (MOAC) recently agreed that the mandatory biodiesel consumption plan for 2036 may be unattainable (given the strategy does not permit reliance on imports) and is therefore being reexamined. Despite an increase in harvested area, crude palm oil (CPO) production, the only feedstock used for biodiesel in Thailand, stagnated at 1.8-2.0 million from 2014-2016 due to unfavourable weather conditions. Thailand experiences a great economic and industrial development and is the second largest energy consumer in South East Asia. Being a net oil importer, Thai government has declared a renewable energy development programme in order to secure sustainable development and energy security. Thailand spends more than $10 \%$ of GDP for energy imports and transport sector accounts for $36 \%$ of total final energy consumption of which $50 \%$ is diesel. Diesel marks a huge impact on Thai economy.
\end{abstract}

\section{Introduction}

Biodiesel is one of the major biofuels for alternative energy sources of Thailand now. In the process of biodiesel producing, one of the main raw materials for biodiesel producing is oil palm, (scientific name of oil palm is Elaeis Guineensis); however, there is some limitation on the amount of oil palm feedstock ready for being raw material for biodiesel processing. The Ministry of Energy of Thailand has released the strategy for biodiesel policy of the year 2012; defining that the B10 biodiesel shall be used nationwide. [1] From the study on the Thailand's biodiesel report, Thailand's biodiesel production capacity for the year of 2015 appeared totally at $2,866.72$ million liters. From the total of such 2,866.72 million liters, 2,230.33 million liters are processed from palm oil feedstock, 473.25 million liters name; jatropha, common name; physic nut, ettlespurge), and 163.14 million liters are processed from used oil [2]. are processed from jatropha oil feedstock (scientific Such the capacity should respond optional diesel replacement capacity demand at the percentage of 9.95 for the year of 2015, and it could be representing the renewable energy cost of diesel imports up to 74,964.73 million baht at current prices as shown in Table 1. In addition, the national increasement of bio - yield will be resulting in massive biodiesel production capacity in Thailand and also will be increasing the yield of biodiesel if the government focuses on agricultural capability of palm oil producing to higher yield and on utilization of modern agricultural technology able to practically raise the yield to that of 2-3 times of the actual one, and also on supporting of regionwide palm plantation to all over agricultural areas of Thailand. [1]

Table 1. Diesel replacement capacity of biodiesel.

\begin{tabular}{|c|c|c|c|c|c|c|}
\hline \multirow{2}{*}{ Year } & \multirow{2}{*}{ Diesel Demand } & \multicolumn{3}{|c|}{$\begin{array}{c}\text { Bio - oil yield for feedstock of biodiesel } \\
\text { producing (million liter) }\end{array}$} & $\begin{array}{c}\text { Diesel replacement } \\
\text { capacity of biodiesel } \\
\text { (percent) }\end{array}$ & $\begin{array}{c}\text { Value } \\
\text { (million baht) }\end{array}$ \\
\cline { 3 - 7 } & & Palm oil & Coconut oil & Total & & \\
\hline 2012 & $26,191.30$ & $2,163.21$ & 0 & $2,163.21$ & 10.35 & $70,863.10$ \\
\hline 2013 & $27,069.20$ & $2,160.87$ & 0 & $2,160.87$ & 10.11 & $71,584.06$ \\
\hline 2014 & $27,947.20$ & $2,186.57$ & 0 & $2,186.57$ & 9.99 & $73,038.26$ \\
\hline 2015 & $28,825.10$ & $2,230.33$ & 0 & $2,230.33$ & 9.95 & $74,964.73$ \\
\hline
\end{tabular}

Note * Calculated from average diesel price, January - September, 2016, at 26.15 baht per liter.

Table 2. Raw palm oil of Thailand Market, 2014 - 2017 (ton)

\footnotetext{
* Corresponding author: chalida.ut@kmitl.ac.th
} 


\begin{tabular}{|c|c|c|c|c|c|c|}
\hline \multirow{2}{*}{ Years } & \multirow{2}{*}{$\begin{array}{c}\text { Early } \\
\text { feedstock }\end{array}$} & Yield & import & Export & \multicolumn{2}{|c|}{ Domestic consumption } \\
\cline { 5 - 7 } & & & & & consumption & $\begin{array}{c}\text { Biodiesel } \\
\text { processed }\end{array}$ \\
\hline 2014 & 204,000 & $2,000,610$ & - & 255,252 & 939,369 & 842,398 \\
\hline 2015 & 167,591 & $2,068,475$ & 53,279 & 68,102 & $1,053,329$ & 833,223 \\
\hline 2016 & 334,691 & $1,814,496$ & - & 56,638 & 970,945 & 890,585 \\
\hline 2017 & 230,929 & $2,162,496$ & - & 70,000 & $1,050,000$ & $1,000,000$ \\
\hline
\end{tabular}

Table 3. Yearly regional coconut product of Thailand

\begin{tabular}{|c|c|c|c|}
\hline Region / Province & \multicolumn{3}{|c|}{ Product (Ton) Coconut } \\
\hline & $\mathbf{2 0 1 4}$ & $\mathbf{2 0 1 5}$ & $\mathbf{2 0 1 6}$ \\
\hline Nationwide & 970,730 & 904,025 & 3,520 \\
\hline Northern & 6,821 & 5,000 & 2,123 \\
\hline Northeastern & 3,598 & 2,890 & 400,745 \\
\hline Central & 419,789 & 419,789 & 451,322 \\
\hline Southern & 516,595 & 476,346 & \\
\hline
\end{tabular}

\section{Property requirements for materials in biodiesel}

\subsection{Oil palm}

For the year of 2016, it had the effective plantation area of 4.56 million rai, up from 4.30 million rai in 2015 , at 6.21 percent with the yield of 11.00 million tons, down from 12.05 million tons in 2015 , at 8.72 percent at the due to continual drought disaster from 2014 to early yield rate of $2,409 \mathrm{~kg}$ per rai, down from 2,803 kilograms per rai in 2015 , at the percentage of 14.06, 2019; having been fed with lower rainfall than that of normal one, the palm bunch yield became hardly grewas shown in Table 2 . However, it always remains the major bio-oil plant favourable for being used as the main raw material for biodiesel production in Thailand because it is the more potential plant for biofuel producing than others; it processes low production cost with high yield production rate. [3]

\subsection{Soybean}

For the years of 2012/13 - 2016/17, soybean plantation areas and its yields were likely to annually decrease by 1.97 percent and 3.42 percent, respectively. In 2016/17, the planting areas were at 0.212 million rai and its yielded at 55,979 tons, reduced from 0.217 million rai and from 56,963 tons for the years of 2015/16 at 2.30\% and $1.73 \%$, respectively [3]. The decrease in planting areas and yields was mainly due to lower benefits than that of other competitive alternative crops and due to being lack of productive soybean breeding seed.

The soybean productive yield per rai in 2012/13 2016/17 annually decreased at 0.47 percent in 2016/17, and that of 2016/17 appeared at 264 kilograms per rai increasing from 262 kilograms per rai for that of $2015 / 16$ at 0.76 percent.

\subsection{Coconut}

Coconut plants have long been economical plant both for consumption and for industries' processes. It has been planted all over regions of Thailand as shown in the table 3 .

That is the major cause to make it lower price compared to other bio-oil products such as sesame oil, soybean oil, rice bran oil, peanut oil, and sunflower oil. Due to the cost of biodiesel processing at $80 \%$ is depending on that of raw material cost, the costs of bio - oils being processed for a raw material of biodiesel processing could be found that price of the raw material, sesame oil, soybean oil, rice bran oil, peanut oil, and sunflower oil were not suitable for being used as bio-diesel raw materials, because of the high costs of such raw materials compared to that of coconut [4]. When having calculated the cost of processed biodiesel, it was found that at the investment of biodiesel production of 6.42 baht per liter (Walailak University, refer to the Department of Naval Shipyard, 2005), It could be seen that the cost of biodiesel from sesame oil, soybean oil, rice bran oil, peanut oil, and from sunflower oil were very high, costing from 33.70 - 63.52 baht. [3] 


\section{Analysis of results}

B100, or biodiesel, in Thailand is currently produced from palm oil-derived feedstock such as crude palm oil (CPO), refined bleached deodorized palm oil (RBDPO), palm stearin, and free fatty acids of palm oil (FFA). Thailand's campaign to utilize used cooking oil for biodiesel production exists among one or two biodiesel companies as a corporate social responsibility campaign; however, the use is limited to 5-6 million liters of unused cooking oil per annum. Biodiesel production is driven by government mandates, mainly aimed to help palm farmers. All palm oil feedstocks used for biodiesel are domestic since the government strictly controls the imports of palm oil [5]. Meanwhile, the blending of biodiesel among petroleum refineries is strictly controlled and monitored to comply with the mandatory biodiesel blending requirements. All domestic diesel is required to meet these blending requirements including diesel for onroad inland shipping, trains, agriculture, and industrial. [2]

\subsection{Marketing}

The demand for raw palm oil in Thailand was likely to increase both for consumption and for biodiesel producing at $1.78 \%$ and at $8.11 \%$, respectively. For 2016 , the demand for crude palm oil for consumption was at 970,945 tons, decreased from 1,053,329 tons in early 2015 , at $7.82 \%$. Raw palm oil demand for biodiesel production is at 890,858 tons, raised from 833,223 tons in 2015 , at $6.88 \%$, due to the demand for actual diesel increased from 58.52 million liters in 2015 to 61.22 million liters in 2016. While, for the years of 2013 - 2016, the demand for soybean breeding seeds has annually increased by 8.03 percent [3]. For 2016 , the demand was at 2.66 million tons, increasing from 2.62 million tons in 2015 , at 1.53 percent. There are many purposive usages of soybean such as for oil extraction, breeding, and for processing of food products; it appears at 67.3 percent, 0.15 percent, and 32.05 percent of the overall soybean seed demand, respectively. [3]

\subsection{Prices}

In case of oil palm, for the years of 2012 - 2015, oil palm and palm oil prices in Thailand are likely to increase following the crude palm oil price in the global market. Additionally, there were more palm oil factories than the marketed palm oil products and resulted in competition of raw palm oil purchasing. The prices of fresh palm always were under movements. The price of fresh palm fruit sold by the farmers over the past 5 years was expected to annually increase by 4.23 percent. In 2016, the average price per kilogram was at 5.50 baht, up from 4.12 baht in 2015 , at the percentage of 33.50 .

In case of soybean, soybean seed and soybean oil domestic prices identically varied to that of the world market and higher global soybean yields. The negotiated price of mix-graded soybean seeds for the year of 2016 could be at 14.47 baht per kilogram, decreased from that of 15.46 baht per kilogram of the year 2015 at the percentage of 6.40 percent. The import price of soybean seeds for 2016 is at 14.43 baht, decreased from that of 2015 from 15.00 baht per kilogram and at the percentage of 3.80. The wholesale price of purified soybean oil for the year of 2016 was at 38.98 baht per kilogram, decreased from 47.48 baht per kilogram of that of 2015 , at the percentage of 18.55 .

In case of coconut, it has been forecasted for the prices as shown in figure 1.

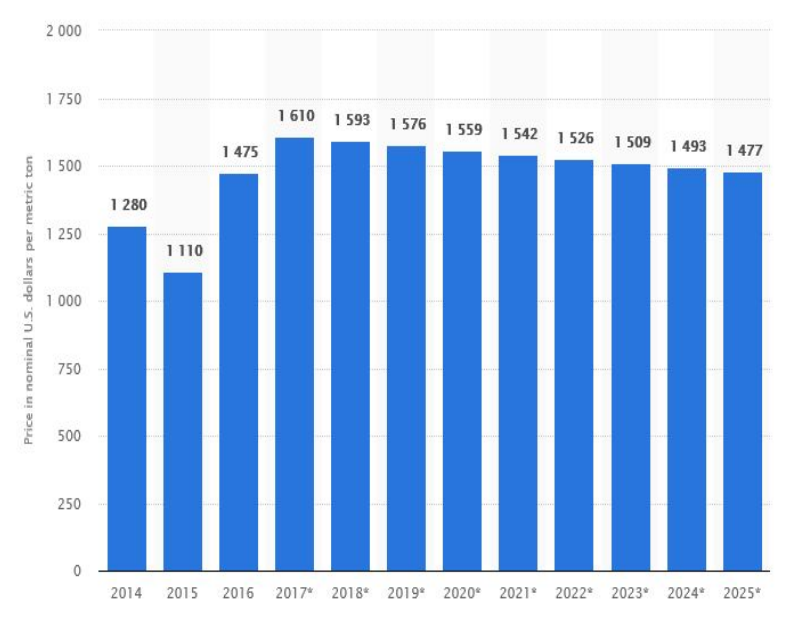

Fig 1. Statistic depicts the average annual prices for coconut.

(Source:https://www.statista.com/statistics/675808/average-pricescoconut-oil-worldwide/)

This statistic depicts the average annual prices for coconut oil from 2014 through 2025. In 2016, the average price for coconut oil stood at 1,475 nominal U.S. dollars per metric ton.

\section{Conclusions}

Based on the results, Thailand is currently implementing their Alternative Energy Development Plan 2015 (AEDP 2015). However, the Ministry of Energy is reportedly revising the plan's targets downward due to lower petroleum price expectations and limited feedstock supplies of ethanol and biodiesel. While the new AEDP plan may not be officially endorsed until late 2017, early revisions reduce the final target for both gasohol and biodiesel consumption in 2036 to 2.6 billion liters each. Thailand experiences a great economic and industrial development and is the second largest energy consumer in South East Asia. Being a net oil importer, Thai government has declared a renewable energy development programme in order to secure sustainable development and energy security. Thailand spends more than $10 \%$ of GDP. 


\section{References}

1. T. Silalertruksa, S. H. Gheewala, Environmental sustainability assessment of palm biodiesel production in Thailand. Energy 2012, 43, 306314.

2. BIODIESEL, THAILAND INDUSTRY OUTLOOK 2017,Available online: https://www.krungsri.com/bank/getmedia/2a1ede0 6-1b73-4282-99d9 3ef7c787714a/IO_Biodiesel_201705_EN.aspx

3. FAO. 2017. Agriculture Statistic(online). Available: http://www.fao.org [2017,September 20]

4. S. Patumsawad, 2nd Generation Biofuels: Technical Challenge and R\&D Opportunity in Thailand. JSEE. Special Issue, 47-50 (2011)

5. FAOStat. Food and Agricultural Organization Statistics. 2012. Available online:http://faostat.fao.org/site/567/default.aspx\#a ncor (Accessed on 1 December 2012) 